HUMAN REPRODUCTION AND DEVELOPMENTAL BIOLOGY 


\section{Human Reproduction and Developmental Biology}

D. J. BEGLEY, BSc, PhD

Lecturer in Physiology,

King's College, London

J. A. FIRTH, MA, PhD

Senior Lecturer in Structural Biology,

St George's Hospital Medical School, London, formerly Lecturer in Anatomy,

King's College, London

J. R. S. HOULT, BA, PhD

Lecturer in Pharmacology,

King's College, London

Illustrations by Lydia Malim

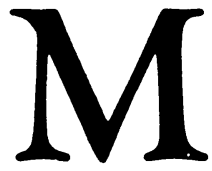


(C) D. J. Begley, J. A. Firth and J. R. S. Hoult 1980

All rights reserved. No part of this publication may be reproduced or transmitted, in any form or by any means, without permission

First published 1980 by

THE MACMILLAN PRESS LTD

London and Basingstoke

Associated companies in Delhi Dublin

Hong Kong Johannesburg Lagos Melbourne

New York Singapore and Tokyo

\section{British Library Cataloguing in Publication Data}

Begley, D J

Human reproduction and developmental biology.

1. Human reproduction 2. Growth

I. Title II. Firth, J A III. Hoult, J R S

612.6

QP251

ISBN 978-0-333-23424-2 ISBN 978-1-349-16260-4 (eBook)

DOI 10.1007/978-1-349-16260-4

This book is sold subject to the standard conditions of the Net Book Agreement

The paperback edition of this book is sold subject to the condition that it shall not, by way of trade or otherwise, be lent, resold, hired out, or otherwise circulated without the publisher's prior consent in any form of binding or cover other than that in which it is published and without a similar condition including this condition being imposed on the subsequent purchaser 


\section{Preface}

The biology of reproduction and development forms a large and cohesive part of the scientific basis of medicine but until recently has not achieved the prominence that it deserves in medical undergraduate teaching. We think that this area of knowledge more than any other demonstrates the fundamental unity of the basic medical sciences and in writing this book we have sought to present the subject in an integrated manner, so reflecting our approach to its teaching. In our experience we have found that the traditional boundaries between the so-called preclinical 'subjects' are often arbitrary and unhelpful.

Our aim has been to explain the biological principles of human reproduction and development by tracing the process from the formation of gametes and their union, through the intrauterine development of the fetus, to birth, growth and ageing. We have also included a chapter on contraception because of its vital importance for the future, but we have excluded any discussion of classical genetics as there are already many excellent texts.

In a book of this size we have not been able to discuss all the topics as fully as we would have liked and so reluctantly we have had to leave out interesting experimental and clinical evidence for many of our statements and conclusions. In spite of this, we hope to show that reproductive and developmental biology rests on a sound experimental foundation. Indeed, the astonishingly rapid advances in this field in the past 20 years are largely due to the development of important new experimental techniques such as radioimmunoassay, electron microscopy and tissue culture.

It is our intention that this book should serve as a useful introduction for medical students and that it may provide a scientific basis for further studies in obstetrics, fertility and paediatrics. We also hope that it will interest students of mammalian biology, midwifery and nursing. We assume that readers will have an elementary working knowledge of physiology, biochemistry, cell biology and human anatomy. At the end of each chapter we have provided some limited suggestions for further reading for those who wish to explore other areas more thoroughly but these lists are not intended to be comprehensive as it is apparent that most students do not have time to use extensive bibliographies.

The task of writing this book has been exacting but enjoyable and has been made easier by the friendly tolerance of our colleagues. We offer special thanks to Lydia Malim whose excellent illustrations speak for themselves. We greatly appreciate the expert manner in which she has interpreted our crude sketches and the high quality of the results.

David Begley

Anthony Firth

King's College, November 1978

Robin Hoult 


\section{Contents}

Chapter 1 The formation of gametes 1

1.1 Introduction 1

1.2 Mitosis and meiosis 1

1.3 Oogenesis $\quad 3$

1.4 Spermatogenesis $\quad 4$

$\begin{array}{lll}1.5 & \text { Spermiogenesis } & 4\end{array}$

$\begin{array}{ll}1.6 & \text { The spermatogenic cycle }\end{array}$

Chapter 2 The female reproductive system $\quad 10$

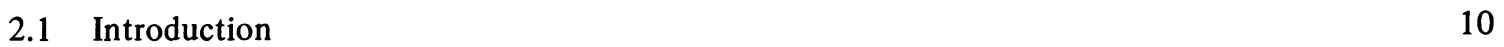

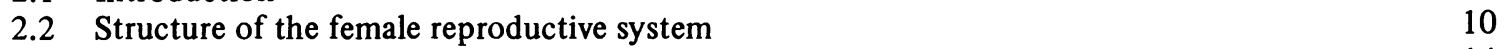

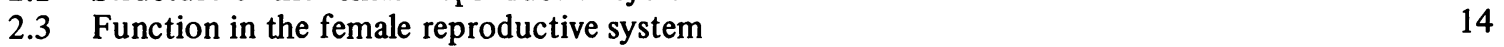

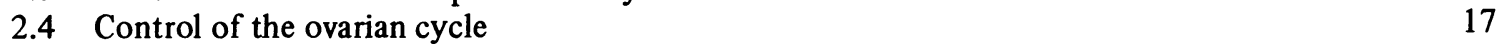

$\begin{array}{ll}2.5 & \text { The endometrial cycle } \\ \end{array}$

2.6 Non-endometrial sites of action of the ovarian steroids $\quad 21$

2.7 Hypothalamic and pituitary control of the menstrual cycle 23

$\begin{array}{ll}2.8 & \text { Hormonal treatment of female infertility } \\ 25\end{array}$

Chapter 3 The male reproductive system $\quad 26$

$\begin{array}{lll}3.1 & \text { Introduction } & 26\end{array}$

\begin{tabular}{ll}
3.2 & Structure of the male reproductive tract \\
\hline
\end{tabular}

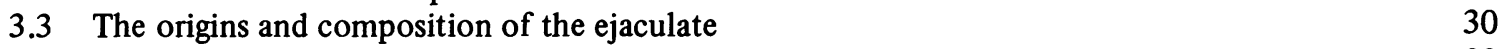

$\begin{array}{lll}3.4 & \text { Seminal analysis and male fertility } & 33\end{array}$

\begin{tabular}{ll}
3.5 & The hormonal control of male reproductive function \\
\hline
\end{tabular}

$\begin{array}{ll}3.6 & \text { Actions of the gonadotropins } \\ 3.7 & 34\end{array}$

$\begin{array}{lll}3.7 & \text { The control of gonadotropin secretion } & 35\end{array}$

$\begin{array}{lll}3.8 & \text { Testosterone } & 36\end{array}$

$\begin{array}{lll}\text { Chapter } 4 & \text { Coitus and fertilisation } & 38\end{array}$

$\begin{array}{lll}4.1 & \text { The role of coitus } & 38\end{array}$

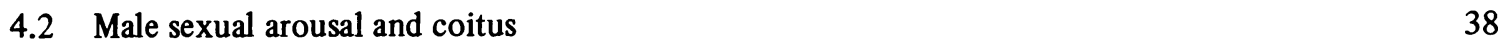

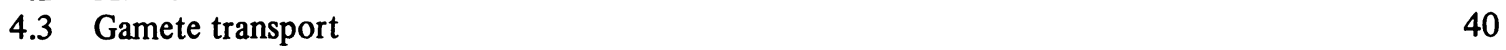

\begin{tabular}{ll}
4.4 & Gamete preparation and capacitation \\
\hline
\end{tabular} 
$\begin{array}{lll}4.5 & \text { The acrosome reaction } & 41\end{array}$

$\begin{array}{lr}4.6 & \text { Penetration of the zona pellucida } \\ 4.7 & 42\end{array}$

$\begin{array}{lll}4.7 & \text { Gamete fusion } & 43\end{array}$

$\begin{array}{ll}4.8 & \text { Polyspermy and its avoidance } \\ 4.9 & 43\end{array}$

4.9 Formation of pronuclei and of the zygote nucleus 44

$\begin{array}{lr}4.10 \text { Other events occurring at fertilisation } & 45\end{array}$

$\begin{array}{lr}4.11 \text { Parthenogenesis } & 45\end{array}$

\begin{tabular}{lr}
4.12 & Fertilisation in vitro \\
\hline
\end{tabular}

Chapter 5 Implantation and establishment of the conceptus 46

$\begin{array}{lll}5.1 & \text { Gene expression in the zygote } & 46\end{array}$

$\begin{array}{ll}5.2 \text { Cleavage } & 46\end{array}$

$\begin{array}{llr}5.3 & \text { Blastocyst formation } & 46\end{array}$

$\begin{array}{ll}5.4 & \text { Nutrition before implantation } \\ 5.5 & \text { Conditions for implantion }\end{array}$

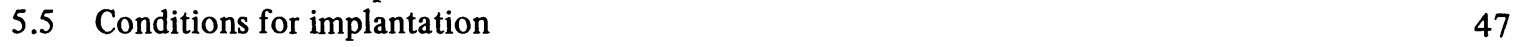

$\begin{array}{ll}5.6 & \text { The mechanism of implantation }\end{array}$

$\begin{array}{lll}5.7 & \text { Maternal responses to implantation } & 49\end{array}$

5.8 Maintenance of an established pregnancy 449

\begin{tabular}{lr}
5.9 & Abnormal implantation sites \\
\hline
\end{tabular}

$\begin{array}{lr}5.10 \text { The foreign fetus } & 50\end{array}$

$\begin{array}{llr}\text { Chapter } 6 \text { Contraception } & 52\end{array}$

6.1 Population growth, family planning and contraception $\quad 52$

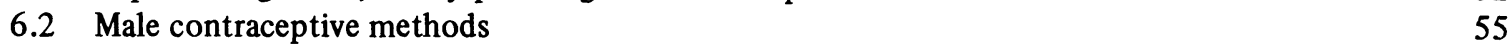

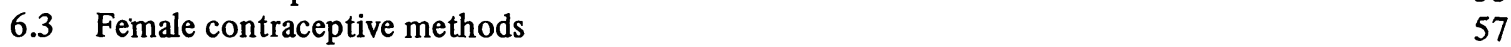

$\begin{array}{lll}6.4 & \text { Oral contraceptives } & 58\end{array}$

$\begin{array}{lll}\text { 6.5 The intrauterine contraceptive device } & 64\end{array}$

6.6 Possible new methods of female contraception 65

6.7 Assessment of risks and benefits of different types of contraceptive 66

$\begin{array}{lll}\text { Chapter } 7 & \text { The placenta } & 68\end{array}$

$\begin{array}{lll}7.1 & \text { Nutrition of developing organisms } & 68\end{array}$

$\begin{array}{lll}7.2 & \text { The yolk sac placenta } & 70\end{array}$

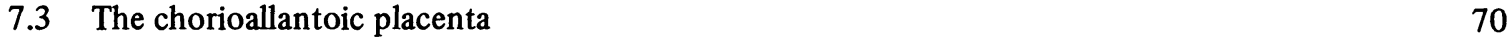

$\begin{array}{ll}7.4 & \text { Development of the 'definitive' placenta } \\ 7.5 & 72\end{array}$

$\begin{array}{lll}7.5 & \text { Factors affecting placental exchange } & 74\end{array}$

$\begin{array}{lll}7.6 & \text { Placental blood flow } & 75\end{array}$

$\begin{array}{lll}7.7 & \text { Barrier characteristics of the placenta } & 77\end{array}$

$\begin{array}{lll}7.8 & \text { Placental transport functions } & 78\end{array}$

\begin{tabular}{ll}
7.9 & Hormone production by the placenta \\
\hline
\end{tabular}

$\begin{array}{lll}\text { Chapter } 8 & \text { Embryogenesis and its mechanisms } & 90\end{array}$

$\begin{array}{llr}8.1 & \text { Approaches to development } & 90\end{array}$

$\begin{array}{ll}\text { 8.2 The mechanics of development } & 90\end{array}$

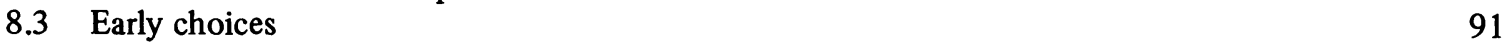

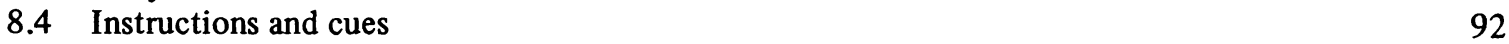

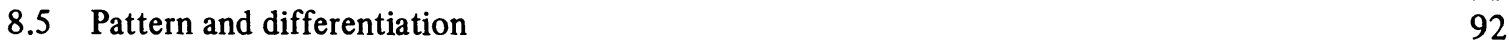

$\begin{array}{ll}\text { 8.6 Developmental fields } & 94\end{array}$ 


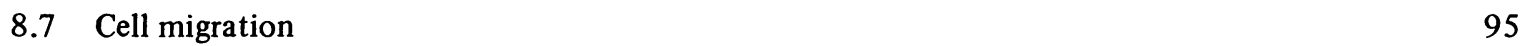

$\begin{array}{lr}8.8 \text { Cell death } & 96\end{array}$

8.9 Explaining development $\quad 96$

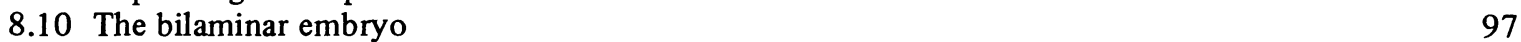

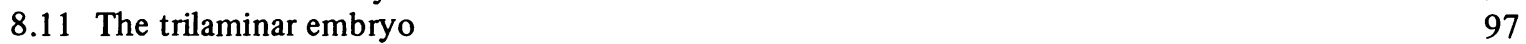

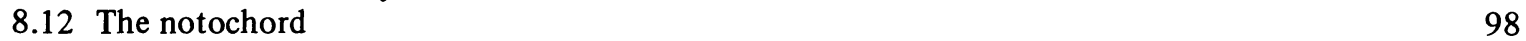

$\begin{array}{lr}8.13 \text { Mesoderm differentiation } & 100\end{array}$

$\begin{array}{lr}8.14 & \text { Intraembryonic coelom and body folds } \\ 8.15 & 102\end{array}$

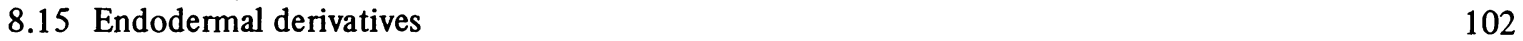

$\begin{array}{lll}\text { Chapter } 9 & \text { The development of organ systems } & 108\end{array}$

$\begin{array}{llr}9.1 & \text { Embryogenesis and organogenesis } & 108\end{array}$

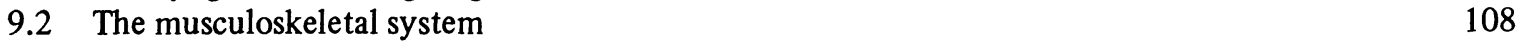

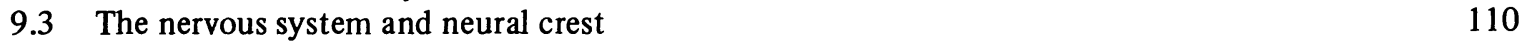

$\begin{array}{llr}9.4 & \text { The cardiovascular system } & 113\end{array}$

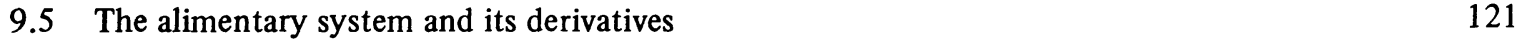

$\begin{array}{ll}\text { 9.6 The genital and urinary systems } & 125\end{array}$

$\begin{array}{lll}9.7 & \text { Limb development } & 128\end{array}$

$\begin{array}{lll}\text { Chapter } 10 & \text { Reproductive failure and wastage } & 133\end{array}$

$\begin{array}{llr}10.1 & \text { Introduction } & 133\end{array}$

$\begin{array}{ll}10.2 & \text { Congenital abnormalities } \\ 1 & 135\end{array}$

$\begin{array}{llr}10.3 & \text { Teratogenesis } & 138\end{array}$

\begin{tabular}{ll}
10.4 & Inborn errors of metabolism \\
\hline
\end{tabular}

$\begin{array}{llr}10.5 & \text { Spontaneous abortion and fetal losses } & 143\end{array}$

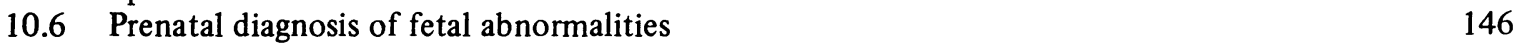

$\begin{array}{lll}\text { Chapter } 11 & \text { Maternal and fetal physiology } & 150\end{array}$

$\begin{array}{llr}11.1 & \text { Introduction } & 150\end{array}$

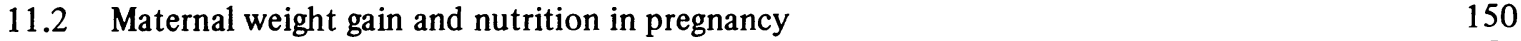

$\begin{array}{llr}11.3 & \text { Fetal growth } & 152\end{array}$

$\begin{array}{llr}11.4 & \text { The maternal cardiovascular system } & 154\end{array}$

$\begin{array}{ll}11.5 & \text { The fetal cardiovascular system } \\ 1156\end{array}$

\begin{tabular}{ll}
11.6 & Maternal blood and body fluids \\
\hline
\end{tabular}

$\begin{array}{llr}11.7 & \text { Fetal blood and body fluids } & 158\end{array}$

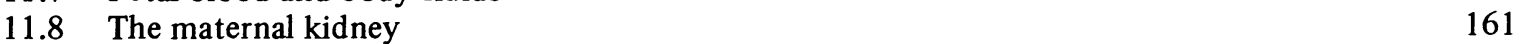

$\begin{array}{lr}11.9 & \text { The fetal kidney } \\ 1102\end{array}$

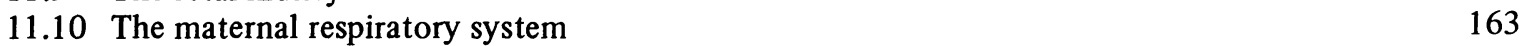

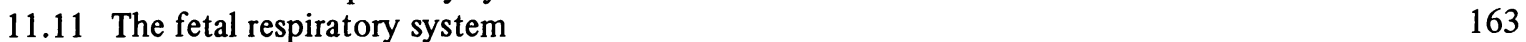

11.12 The fetal gastrointestinal tract $\quad 165$

11.13 The fetal endocrine system $r$

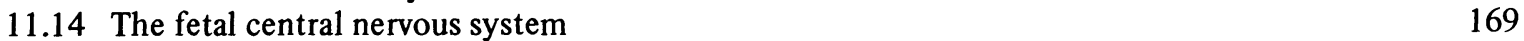

$\begin{array}{ll}11.15 & \text { Other metabolic changes in the mother during pregnancy } \\ \end{array}$

Chapter 12 The initiation and course of labour 172

$\begin{array}{llr}12.1 & \text { Introduction } & 172\end{array}$

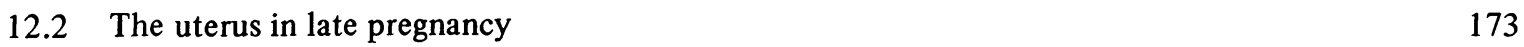

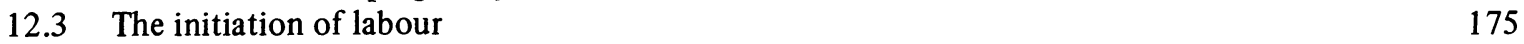




\section{$x$ Contents}

12.4 Mechanisms and progress of labour: events leading to the first stage 177

$\begin{array}{lll}12.5 & \text { First stage of labour } & 178\end{array}$

$\begin{array}{lr}12.6 & \text { Second stage of labour } \\ 12.7 & 180\end{array}$

$\begin{array}{llr}12.7 & \text { Third stage of labour } & 183\end{array}$

$\begin{array}{lll}12.8 & \text { The puerperium } & 184\end{array}$

12.9 Analgesia and anaesthesia in labour

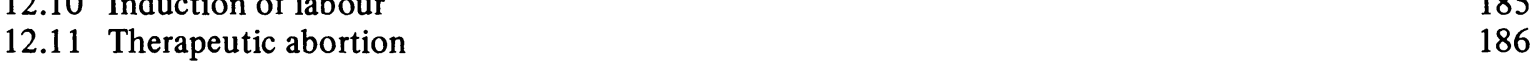

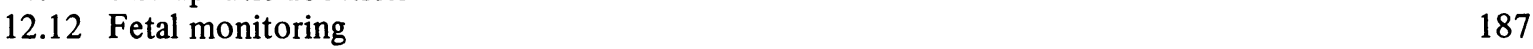

$\begin{array}{lll}\text { Chapter } 13 & \text { Adaptations of the newborn to extrauterine life } & 189\end{array}$

$\begin{array}{llr}13.1 & \text { Introduction } & 189\end{array}$

13.2 The effects of birth on the infant $\quad 189$

$\begin{array}{ll}13.3 & \text { Initiation of ventilation } \\ 13.4 & 190\end{array}$

\begin{tabular}{ll}
13.4 & Cardiovascular changes at birth \\
\hline
\end{tabular}

13.5 The respiratory system of the newborn 193

13.6 The cardiovascular system of the newborn 194

13.7 Metabolism in the newborn 196

13.8 Temperature regulation in the newborn $\quad 198$

13.9 The neonatal kidney $r$

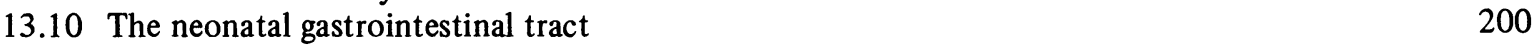

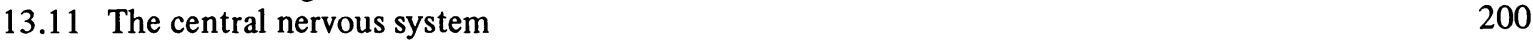

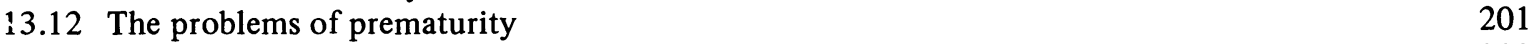

$\begin{array}{lr}13.13 \text { Mortality in early life } & 202\end{array}$

$\begin{array}{lll}\text { Chapter } 14 & \text { The breast and lactation } & 204\end{array}$

$\begin{array}{lll}14.1 & \text { Introduction } & 204\end{array}$

14.2 Structure and function of the adult mammary gland 204

\begin{tabular}{ll}
14.3 & Embryological development of the mammary gland \\
\hline
\end{tabular}

$\begin{array}{ll}\text { 14.4 Growth of the breast from birth through puberty and until pregnancy } & 208\end{array}$

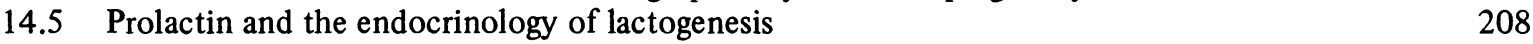

$\begin{array}{ll}\text { 14.6 Control of prolactin secretion } & 209\end{array}$

$\begin{array}{lll}14.7 & \text { The alveolar cell } & 210\end{array}$

$\begin{array}{ll}14.8 \text { Milk } & 212\end{array}$

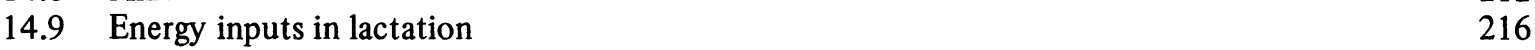

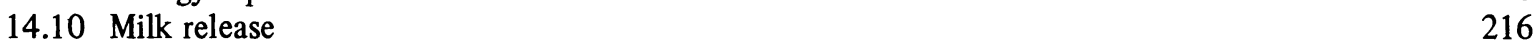

$\begin{array}{ll}14.11 \text { Colostrum } & 218\end{array}$

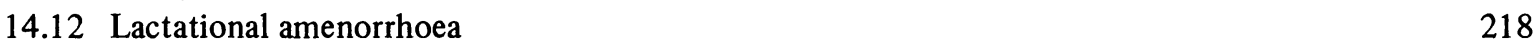

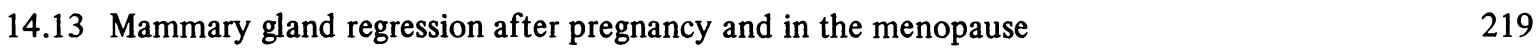

$\begin{array}{lll}\text { Chapter } 15 & \text { Growth, puberty and ageing } & 220\end{array}$

$\begin{array}{lll}15.1 & \text { Growth } & 220\end{array}$

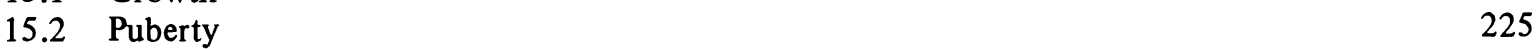

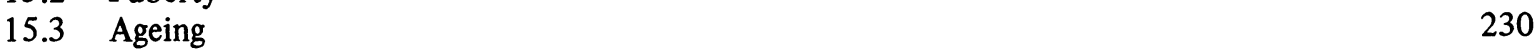

15.4 Decline of sexual function with age $\quad 233$

$\begin{array}{lr}\text { Index } & 239\end{array}$ 